\title{
BUTTERFLIES OF KRISHNAPURAM GRAMA PANCHAYATH, ALAPPUZHA DISTRICT, KERALA - A CASE FOR REVISED STUDY
}

\author{
C. Radhakrishnan \\ Zoological Survey of India, Western Ghats Field Research Station, Annie Hall Road, Calicut, Kerala 673002, India
}

Forty species of butterflies were recorded from Krishnapuram Grama Panchayath, Alappuzha District, Kerala by Biju Babjan and Archana (1999). Based on the habitat requirements, a number of butterfly species recorded in Krishnapuram are not likely to occur there as the Panchayath falls in a low lying area with a floral pattern comprising of mixed crop vegetation. With a vast area of agricultural land, this village is a very unlikely habitat for the following species recorded in the study.

1. Euploea klugii Moore - The Brown King Crow: The species is not rare. Though found also in low elevations in southern India, it prefers wet jungle habitats.

2. Idea malabarica (Moore) - The Malabar Tree Nymph: The species is a southern Indian endemic, limited to wet evergreen forest of the Western Ghats system.

3. Charaxes bernardus Fabricius - The Tawny Rajah: Limited to the lowland evergreen forests such as the jungles at the foot or lower slopes along the Western Ghats.

4. Kallima horsfieldi Kollar - The South Indian Blue Oak Leaf: The species is endemic to the Western Ghats system and largely limited to evergreen forests.

5. Abisara echerius (Stoll) - Plum Judy: In peninsular India, the species is confined to the wooded and hilly areas seldom venturing out of its haunts being a shade lover. Mainly found in lowland and subtropical evergreen forests and not in the plains.

6. Amblypodia anita Hewitson - The Leaf Blue: A fast flier keeping to reasonably undisturbed forested regions and never seen in open country.

7. Chilasa clytia (Linnaeus) - The common Mime: This butterfly is found in hilly regions usually at low elevations. The main habitat appears to be mixed dry-deciduous forests at low levels and the lowland ever-green forest.

Received 30 September 1999;

Accepted 29 November 1999
8. Pathysa nomius (Esper) - The Spot Swordtail: A species not often found away from hilly and forested country. Generally a species of dry mixed deciduous forests.

9. Colotis eucharis (Fabricius) - The Plain Orange tip: More of a dryland species found normally at the foothills but also found in the plains.

10. Pieris canidia (Sparrman) - The Indian Cabbage White: In southern India, the species is found in the higher ranges frequenting shrubs and bushes keeping out of forests.

11. Celaenorrhinus ambareesa (Moore) - The Malabar Spotted Flat: The normal habitat of the species is jungle in the wetter, hilly parts. A shade lover in habit, this butterfly seldom ventures out of its jungle haunts.

The above are apparently cases of misidentification which in turn make rest of the species identification suspect. Otherwise, they form interesting distributional records.

To conclude, Wynter-Blyth (1957) discussing an unusual habitat record of The Spot Swordtail, Pathysa nomius (Esper) is quoted, "It is the business of the Lepidopterist to attempt to solve these problems. It is most important that the fullest details of such captures should be preserved. Unconfirmed information or incompletely labelled specimens are useless as data, and the collector should always be on his guard against interesting information from sources that are not absolutely reliable".

\section{Acknowledgement}

The author is grateful to the Director, Zoological Survey of India, Calcutta for facilities and encouragement.

\section{References}

Biju Babjan and Archana (1999). Butterflies of Krishnapuram Grama Panchayath, Alappuzha District, Kerala. Zoos' Print Journal 14(6): 42.

Wynter-Blyth, M.A. (1957). Butterflies of the Indian Region. The Bombay Natural History Society, Bombay, 523 pp. 